\title{
The Left Reflects on the Global Pandemic and Speaks to Transform!
}

\author{
Gayatri Chakravorty Spivak
}

Received: 5 August 2020 / Accepted: 29 September 2020

(C) Journal of Bioethical Inquiry Pty Ltd. 2020

\begin{abstract}
The structure of this intervention is deliberately schizo-analytic: "and then_-," and "then_-." They are preparatory notes for a webinar by Transform! Europe on the COVID, arranged before the global explosion of Black Lives Matter. I question the top-down philanthropy of the bourgeois Left. I take the Rohingyas as bottom-line victims. I speak from two hometownsCalcutta and New York. I ask the bourgeois Euro-U.S. Left not to monolithize the Global South. Many examples of how "India" is constructed are given. From New York, the United States is declared a failed state. Trump's delinquencies are mentioned. It is argued that the only remedy at present is human behaviour and the typical U.S. character is not ready to practice this. This empirical fact shows the failure of the Kantian Sublime and reminds us that Kant thinks that the human moral will comes in to protect us from a hugely frightening natural phenomenon only by "subreption," the same impulse that says that following steps provided by institutional religion will absolve us. Class and caste are taken into consideration throughout. I mention that as a coronavirus convalescent, I am donating plasma regularly.
\end{abstract}

Keywords Caste $\cdot$ Class $\cdot$ India $\cdot$ Kantian sublime . Rohingyas · United States

G. C. Spivak ( $\square)$

Columbia University, New York, NY, USA

e-mail: gcspiv@gmail.com “transform!" writes:

As humanity faces the catastrophic COVID-19 pandemic ... the Left internationally must address this crisis with ... action, analysis and planning; ... building solidarity networks and launching campaigns to protect and work alongside the people ... hardest hit ... We must think strategically and present alternatives for the future. We cannot allow the global reimposition of a failed system on the people. The radical left will pose alternatives to reinvent socialist politics for the 21st century: to build a new society that empowers and liberates us all. (transform! 2020)

My question: Who are "we" to offer these top-down solutions?

\footnotetext{
A Failed State

No, this is NOT from the "radical left" but from a West Point Graduate and Rabbi:

How does one maintain his patriotic oath in the age of the failed state?

Citizens relinquish money and authority to governments first and foremost in exchange for protection from threats that they, as individuals and communities, cannot hope to confront. By outspokenly rejecting this fundamental responsibility, our federal government has clearly illustrated that ... America is a failed state- one whose institutions no longer serve their intended purposes. (Knobel 2020)
} 


\section{Rohingyas}

As we consider this phantasmagoria of bio-politics, let us start with the Rohingyas. According to the United Nations, they are the ethnic Muslim group that is a victim of genocide at least since 2017 , with rape used as a weapon, by the majority ethnic Buddhist state and military in Burma. They have been in camps in Malaysia, which wants them to leave (although they have become leverage in party politics) and they have been in camps in Bangladesh. At the moment, because of coronavirus, the NGOs have left them, the United Nations Refugee Agency (UNHCR) has left them, and of course they have no way of making themselves safe from anything. Here at least, a course of action can be suggested. Work with a large international civil society organization, bonded as they are with corporate funding, to turn them around persistently so that they can be active with the Rohingyas again. I say to the unemployed PhD's at universities in Europe and the United States, where I teach, that this is a field where there is employment and work to do. The Rohingya are often in wooden boats in the open sea, where

... [m]en live crammed below deck, with only space to crouch. Women and children are above deck, but all struggle for food; around half a cup of water on a good day, and a couple of mouthfuls of rice at $4 \mathrm{pm}$... Refugees are beaten by the traffickers. [Large numbers of] people are reported as dying on these boats. (Rigby 2020, II8)

Médecins Sans Frontières, which treated some survivors when they made it back to Bangladesh — including some young children - said that most of the survivors couldn't stand or walk on their own when they reached the shores. Even before the virus, many among the Rohingya described their life as "subhuman."

See link 1-https://docs.google.com/presentation/d/1 Ob02HgEvyKgyn4-n883hDQTPI9JQ4sTuGTzqg3z9 Deo/edit\#slide=id.p1. ${ }^{1}$

They are always on the threshold of whatever I have to say, because I cannot imagine their condition. This goes also for war zones, within which the condition of women is worse still.

\footnotetext{
${ }^{1}$ For more detail regarding the links contained in this article please contact the corresponding author.
}

\section{Speaking for Two Hometowns: 1. Calcutta}

Being safe, masked and gloved, and physically distanced against COVID-19 is for the middle class. Let us look at two pictures. The first one, sent to me by my sister Maitreyi Chandra, who lives in Delhi, shows us that our hometown Calcutta, usually super-crowded, is empty.

See link 2- https://docs.google.com/presentation/d/1 Ob02HgEvyKgyn4-n883hDQTPI9JQ4sTuGTzqg3z9 Deo/edit\#slide=id.p2 ${ }^{2}$

And the second one, sent to me by a rural high school teacher who wrote the words to the accompanying song, shows the highways right outside of Calcutta as tremendously crowded with migrant labourers walking home hundreds of miles to die.

See link 3-https://docs.google.com/presentation/d/1 Ob02HgEvyKgyn4-n883hDQTPI9JQ4sTuGTzqg3z9 Deo/edit\#slide=id.p $3^{3}$

Migrant laborers are the worst off in Saudi Arabia, the indigenous worst off in Brazil, and "essential" workers - racialized and gendered only a little bit better off than the homeless in my other hometown New York, from where I speak.

Class. But also politics. Here is a "rural" video put forward by the ruling party which my sister sent me.

See link 4 - https://docs.google.com/presentation/d/1 Ob02HgEvyKgyn4-n883hDQTPI9JQ4sTuGTzqg3z9 Deo/edit\#slide=id.p4 ${ }^{4}$

Let me quote a few passages from the conversation between my sister and me about this video-my sister lives in Delhi, myself in New York:

ME: Reminiscent of Trump. Not a word about cleanliness, or distance, just standing close together, singing from a written script, the government woman has a "just doing my job" expression; the song says protest is stupid and the government will give you money. Sung on behalf of the BJP panchayat in Chandipur Block, East Medinipur. How many villagers do you think are taken in by this? Sorry to be so critical, but I know the

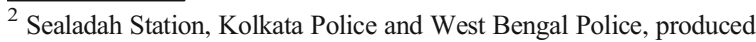
by Genesis n.d.

3 "The metropolis has shut and bolted its doors. All laborers are suddenly unwanted." Artist: Bharatiyo Gananatya Sangha. Lyrics: Santosh Karmakar.

${ }^{4}$ Panchayat song, Video by East Medinipur Panchayat, West Bengal.
} 
violence behind this kind of propaganda so very well, so personally.

SHE: Bia Bhai, why should I think you were scolding me?! I sent it to you to give you some idea how things could be in the villages in Bengal. Things in North Indian cities are very different, since in these cities, people from villages of Bengal, Bihar, UP, come as labourers working daily, eating daily. Thousands and thousands of daily wage labourers are WALKING back, they all want to go home, since they have no work, no earning, no food for their family. The idea is "if we have to starve to death, it's best to die with family." So the government, are trying to tell them that they should stay back, they will be given money and food ..., how important it is to have "social distancing" for avoiding catching the virus ... We do not get to see what is happening in fact in the North Indian villages. In this entire current episode of "corona virus," nobody is speaking about the importance of cleanliness, the emphasis is entirely on "social distancing" and about Government giving, food, money, shelter ... Where is the scope of "social distancing" for this humanity? The Central Government HAS announced "a package" but as I wrote, it was announced two days AFTER the lockdown was announced, so by then the "harm" was done, large migration back to the villages had started, WITHOUT any means of transportation and any food shelter on the way. Delhi government [more democratic socialist like New York] started its activity as soon as was possible, but how can they "catch" those who have already left Delhi? [AND THEN TODAY]: After almost two months (why this delay?) the Central Government has now made arrangements by bus as well as train to carry the daily wage labourers to their home state. Thousands and thousands of such people both male and female with children, have already walked hundreds of miles, some died ...

The worst is, the daily wage earners who have had zero earnings for the last two months, apparently are paying for the train tickets!! (Apparently will be reimbursed by the concerned States once they reach). The lockdown had been extended till $17^{\text {th }}$ May. The daily wage earners, on whose strength the small and medium scale industries (MSME) and agriculture industry run, think that since they are going home now (so late that is), will they come back again almost immediately, as the lockdown gets over, to resume their work?!!
The next slide shows us something manufactured for the upper-middle-class - classical music with English subtitles.

See link 5-https://docs.google.com/presentation/d/1 Ob02HgEvyKgyn4-n883hDQTPI9JQ4sTuGTzqg3z9 Deo/edit\#slide=id.p $5^{5}$

I guess I am saying to benevolent left Europeans as well as U.S. folks: do not monolithize the global South. Or, if you must, here's a suggestion from Mithu Sen, a Calcutta-based artist, on how to do it.

See link 6- https://docs.google.com/presentation/d/1 Ob02HgEvyKgyn4-n883hDQTPI9JQ4sTuGTzqg3z9 Deo/edit\#slide=id.p6 ${ }^{6}$

Many people, rightly concerned, email about how terribly my rural schools must be faring, even as they know that in their own countries people who can are removing themselves to rural areas to escape the virus. And in those caste-ridden rural areas, I try to make the ones I work with think about the migrant laborers as much less fortunate than they.

Class is complicit with the caste system and with nationalism. And in fact, if one understands caste broadly rather than within Hinduism, this is also the case almost everywhere.

\section{Other Hometown: New York}

Donald Trump did not start serious centralized preparation on time and he is still interested in cheerleading for himself rather than centralizing. Also, his position is prohibitively nationalistic. Most of us in New York have been symptomatic in a minor way, understandably with no possibility of testing, necessarily risking ourselves since we must continue to live. That situation has changed somewhat now. I am unhappy about Zoom teaching of the humanities, since one-on-one training in imaginative activism, which is the long-term preparation for democratic behaviour, emphasizing not only autonomy or "my rights" but "other peoples' rightspeople who do not resemble me at all" and even the rights of future generations. As universities are corporatizing and humanities pruned (I am a candidate for pruning, because I'm old-although I work like a dog),

\footnotetext{
5 "Na Corona karo," from Sandeep D. Ranade—-sandeepranade.com ${ }^{6}$ Mithu Sen. 2019. "How to be a SUCKsessful Artist"https://mithusen.com/
} 
it may well be that this Zoom teaching of the humanities will take hold and contribute to ethico-political death.

I love New York. So did my mother. The current Mayor has a socialist streak that he is obliged to fight against most of the time. The Governor has solid liberal instincts but still it is we care this way because we're Americans - as you hear from the government. We are this way because we're New Yorkers - as you hear from the mayor. The only "global" noises are made by the liberal British - Gordon Brown as reported on the BBC and others of that ilk-because they are still ideologically self-interpellated as the old global empire. There has been a call by Gorbachev, for comparable reasons.

Much is being made visible by the coronavirus situation, of course. Not only that "essential" workers are gendered and racialized but even that the underpinnings of the welfare state in the United States - the New Deal itself-were racialized.

Globally, I am troubled by the weighing of human life against the economy, of the large-scale preference given to corporate giants.

The most powerful concept-metaphor for the pandemic as well as the virus which is its primum mobile is the Kantian sublime, both dynamic - the virus's terrifying image of movement, much bigger than human society, and mathematical — reduced everywhere to statistics. The human being fears the sublime, which belongs to nature - unlike bacteria, the virus does not live inside the human body in an amphibolic way. But then, surreptitiously, because we know how to save ourselves, we get the sense that that terrifying thing has no mind, whereas we, as human beings, have the moral will. The moral will should lead to the golden rule - treat others as you would like to be treated yourself. This does not emerge in the current context. We are no longer civilized in Kant's sense.

I am seventy-eight, I am post-tubercular-I had coronavirus, was cured, tested negative, donate plasma regularly. I go down to the river and walk back up. The number of people, generally young white men, families, or well-dressed upper-class folks of colour, who walk maskless is amazing. And this is where you see and hear the statement that South Korea or China got out of the pandemic because they don't mind listening to what the state tells them to do whereas we are different, we have freedom of choice-yes freedom choice to be self-interested. To put money over people. To fight something like the emergence of something like socialism. Of course, there are wonderful things like congratulating the front-line workers. I too sometimes open my window and ring the bell that I was given by a people's collective in Bangladesh. But it is also true that every bit of help for the so-called frontline workers gets capitalized — raising funds - and congratulated as such.

\section{References}

Knobel, J. 2020. COVID exposed America as a failed state. How can I honor the military oath I swore? Forward, May 4. https://forward.com/opinion/445503/covid-exposedamerica-as-a-failed-state-how-can-i-honor-the-militaryoath/. Accessed August 9, 2020.

Rigby, J. 2020. "Many people died in front of me": Hundreds of Rohingya stranded on refugee boats in Bay of Bengal. The Telegraph, May 3. https://www.telegraph.co.uk/globalhealth/climate-and-people/many-people-died-fronthundreds-rohingya-stranded-refugee-boats/. Accessed August 13, 2020.

transform!. 2020. The reflects on the global pandemic [webinar]. April 07. https://www.transform-network. net/calendar/event/the-left-reflects-on-the-global-pandemicleo-panitch/. Accessed August 9, 2020.

Publisher's note Springer Nature remains neutral with regard to jurisdictional claims in published maps and institutional affiliations. 